LICENÇA CC BY: Artigo distribuído sob os termos

Creative Commons, permite uso e distribuição irrestrita em qualquer meio desde que o autor credite a fonte original.

\section{PRÁTICAS EDUCACIONAIS E NOVAS CORPOREIDADES DANÇANTES EM ESPAÇOS E TEMPOS DE MEDIAÇÃO TECNOLÓGICA}

EDUCATIONAL PRACTICES AND NEW DANCING CORPOREALITIES IN TECHNOLOGY-MEDIATED SPACES AND TIMES

PRÁCTICAS EDUCATIVAS Y NUEVAS CORPOREIDADES DANZANTES EN ESPACIOS Y TIEMPOS DE MEDIACIÓN TECNOLÓGICA

Cristiane Wosniak ${ }^{1}$

${ }^{1}$ Faculdade de Artes do Paraná, Universidade Estadual do Paraná, Curitiba, PR, Brasil.

Artigo recebido em: 21/01/2020

Aprovado em: 04/11/2020

Resumo: Este trabalho tem por objetivo desenvolver uma reflexão sobre práticas educacionais, ancoradas nas competências docentes exigidas pela era da ubiquidade digital e inseridas no âmbito de um curso de formação de artistas-docentes de dança em uma instituição pública de ensino superior no Paraná. O objeto empírico da investigação é constituído pelo projeto avaliativo na disciplina "Crítica de Dança", que integra a grade curricular do referido curso. Trata-se de uma pesquisa qualitativa com abordagem metodológica de revisão bibliográfica associada a um estudo de caso do tipo exploratório. A reflexão aqui proposta fundamenta-se na teoria sociocultural de Vigotski, no conectivismo proposto por Siemens, nos pressupostos da educação para/na era digital de Pérez Gómez e Dede, bem como nas noções de educação ubíqua propostas por Santaella. Neste estudo, foi possível evidenciar a eclosão de novas corporeidades dançantes que emergem em contextos de (des)articulação digital, utilizando como parâmetro discursivo a criação de videodanças, elaboradas pelos alunos com o uso de seus smartphones. Como resultado, além da criação de videodanças, também foi possível observar que as mediações tecnológicas ubíquas alteram a maneira como nos relacionamos com as artes do corpo que, por sua vez, amplificam a linguagem da dança graças à disseminação em múltiplas telas digitais.

Palavras-chave: Práticas Educacionais; Artes do Corpo; Mediação Tecnológica.

Abstract: This work analyzes some educational practices anchored in the teaching competences demanded by today's age of digital ubiquity, in the scope of a training course for teacher-artists of dance, at a Brazilian public university in the state of Paraná. Its empirical research object consists of an evaluation project carried out for the discipline "Dance Criticism", which is part of the course curriculum. This study applies a qualitative research methodology that includes a bibliographic review 
associated with an exploratory type of case study. The theoretical framework used for this study is a combination of Vigotski's sociocultural theory, Siemens' connectivist learning theory, Pérez Gomes and Dede's educational assumptions for/in the digital age, and Santaella's notion of ubiquitous learning. Through this study, the beginnings of new corporealities were observed, that have emerged in contexts of digital (dis)articulation, having as a discursive parameter video dances created by students using their smartphones. As a result, in addition to the creation of video dance, it was also found that ubiquitous technological mediations are changing the ways we relate to the body arts which, in turn, amplify the language of dance, through its dissemination on multiple digital screens.

Keywords: Educational practices; Body Arts; Technological Mediation.

Resumen: Este artículo tiene como objetivo reflexionar sobre las prácticas educativas, ancladas en las habilidades de enseñanza requeridas por la era de ubicuidad digital, insertadas en una carrera de capacitación de maestros-artistas de danza de una universidad pública en Paraná. El objeto de la investigación empírica es un proyecto de evaluación usado en la disciplina "Crítica de Danza" que forma parte del plan de estudios de la carrera. Esta es una investigación cualitativa con un enfoque metodológico de revisión bibliográfica asociada con un estudio de caso del tipo exploratorio. El ancla teórica que subyace a la reflexión es la teoría sociocultural de Vigotski, el conectivismo tal como lo explica Siemens, los supuestos de educación para/ en la era digital de Pérez Gomes y Dede, y las nociones de educación ubicua propuestas por Santaella. A lo largo del estudio se pudo resaltar la aparición de nuevas corporeidades de la danza que emergen en espacios y tiempos de (des) articulación digital, utilizando como parámetro discursivo la creación de videos danzas, elaboradas por los estudiantes con el uso de smartphones. Como resultado, además de la producción de video danza, también se pudo concluir que las mediaciones tecnológicas ubicuas alteran la manera en que nos relacionamos con las artes del cuerpo, que a su vez amplifican el lenguaje de la danza a través de la difusión en múltiples pantallas digitales.

Palabras clave: Prácticas educativas; Artes del cuerpo; Mediación Tecnológica.

\section{Introdução}

O contexto sociocultural em que estamos imersos de forma irreversível graças ao desenvolvimento tecnológico decorrente da era digital vem nos transformando em seres ubíquos. Por ubiquidade, Lúcia Santaella entende o "atributo ou estado de algo ou alguém que se define pelo poder de estar em mais de um lugar ao mesmo tempo [...] potencializado pela portabilidade conectada, disseminada por toda parte" (SANTAELLA, 2013, p. 128). Em função da hipermobilidade e da portabilidade móvel, anunciada pelos smartphones ${ }^{1}$ e por artefatos digitais similares, designados por Santaella (2013; 2007) como "equipamentos periféricos", é possível vislumbrar o surgimento de uma nova corporeidade mediada por dispositivos digitais.

A era da ubiquidade acaba por criar espaços e tempos de fruição mais fluidos, dispersos e rizomáticos, não apenas nas redes de comunicação, mas também nos próprios deslocamentos efetuados pelos sujeitos contemporâneos em suas conexões permanentes com essas extensões tecnológicas - aparelhos de telefonia celular com câmeras fotográficas e filmadoras, que constituem o foco específico desta investigação - que impactam as suas 
relações com ambientes profissionais, paisagens urbanas, formas de lazer, serviços on-line e com os corpos/mentes que interagem entre si mediados pelas redes sociais.

Ao transferir essas sondagens para a área da Educação, é possível constatar que a onipresença da informação como entorno simbólico de nossas redes de socialização interferem também na ubiquidade da aprendizagem afetando, dessa maneira, as próprias práticas educativas em ambientes de ensino formal, não formal e informal². A educação na era digital exige, portanto, uma atenção especial para uma possível pedagogia da ubiquidade amalgamada às noções de Tecnologias de Comunicação e Informação (TICs) que, cada vez mais, figuram no epicentro das discussões sobre processos de mediação no âmbito educacional contemporâneo.

Inserido neste contexto, o presente artigo propõe uma reflexão sobre práticas educacionais, ancoradas nas competências docentes exigidas pela era da comunicação ubíqua, inseridas na esfera de um curso de formação de artistas-docentes ${ }^{3}$ (o Bacharelado e Licenciatura em Dança da Universidade Estadual do Paraná, campus de Curitiba II/Faculdade de Artes do Paraná, instituição doravante referida como Unespar/FAP). Deve-se mencionar que esta dupla habilitação simultânea, ainda em voga em algumas instituições de ensino superior no país artista e docente - ou, mais precisamente, bacharelado e licenciatura, atua concomitantemente na formação do que se entende por artista-docente na contemporaneidade. O âmbito da grade curricular deste curso assume firmemente o fluxo incessante entre as dimensões pedagógicas e artísticas, ou seja, entre a criação artística, a pesquisa e a prática docente na formação dos profissionais da educação nas artes do corpo/dança.

O objeto empírico desta investigação constitui-se de um recorte da disciplina "Crítica de Dança", lecionada pela autora desta investigação no ano de 2018 e que faz parte da grade curricular do referido curso de graduação. A partir de uma abordagem qualitativa e interdisciplinar, envolvendo uma ampla revisão bibliográfica e com aportes advindos de um estudo de caso complementar do tipo exploratório, o objetivo deste trabalho é evidenciar a eclosão de novas corporeidades dançantes que emergem em contextos de (des)articulação digital. Para isto, será utilizado como parâmetro de discussão o projeto de avaliação na disciplina, fundamentado na criação de videodanças, elaboradas pelos alunos com o uso das câmeras de seus aparelhos celulares - ferramenta tecnológica simbólica - na tentativa de compreender de que forma e com que meios as interfaces midiáticas alteram as maneiras como nos relacionamos com a abundância de informação, imagens em movimento e as artes do corpo na contemporaneidade.

É perceptível o fato de que, "diferentemente de outras épocas, hoje o problema não está na escassez de informação, mas na sua abundância e na necessidade de desenvolver habilidades de seleção, processamento, organização e aplicação crítica e criativa de tal informação" (PÉREZ GÓMEZ, 2015, p. 50 - grifo nosso). A opção pelo estudo de caso proporciona a oportunidade de investigar um fenômeno contemporâneo dentro de seu contexto da vida real - sala de aula na esfera universitária - e fortalece a crença de que o referido processo avaliativo é pertinente 
para situar as reflexões empreendidas no estudo de revisão bibliográfica.

A ancoragem teórica que fundamenta a reflexão é a teoria sociocultural de Vigotski ${ }^{4}$ (2001a; 2001b; 2010), a partir de uma das versões atualizadas do construtivismo social - o conectivismo proposto por Siemens (2005) - , os pressupostos da educação para/na era digital de Pérez Gómez (2015) e Dede (2007), além das discussões acerca da educação ubíqua propostas por Santaella $(2007 ;$ 2013). Para a compreensão e a complementação dos aspectos envolvidos na concepção de corpo contemporâneo, subjetividade e tecnologias digitais em imagens portáteis em tempos de dispersão e hiperconexão, recorre-se a Chagas (2019).

Diante do acima exposto, é preciso admitir, com urgência, que não há mais como negar a polivalência das extensões tecnológicas em nosso cotidiano. Desta forma, apresenta-se aqui uma proposta alternativa de avaliação em que os artefatos móveis podem ser incorporados ao contexto do ensino de formação superior como uma potencialidade para a reconfiguração das formas de verificação de aprendizagem híbridas e abertas que possibilitam novos olhares para processos de criação espontâneos, assistemáticos e rizomáticos, partindo de uma pedagogia ubíqua e centrada nos sujeitos da aprendizagem, "porém particularmente preocupada com a riqueza cultural dos contextos que cercam a vida social e acadêmica de cada indivíduo e lhe oferecem diferentes oportunidades para aprender" (PÉREZ GÓMEZ, 2015, p. 49). Assim, novos paradigmas podem se abrir para a educação sensível e estética, aflorada a partir dessa relação cambiante entre o dispositivo móvel e as imagens de corporeidades dinâmicas.

\section{O Desenvolvimento de Competências Docentes na} Era Digital

As avançadas tecnologias da comunicação no século XXI transformaram a natureza das ferramentas de informação e, por consequência, os processos de ensino, aprendizagem e comunicação humanos. Em Educação na era digital: a escola educativa, Pérez Gómez (2015, p. 23) afirma que "na era da informação global-digital, a cognição, tanto conteúdos como os processos, encontra-se distribuída e dispersa entre mentes humanas, meios digitais, grupos de pessoas, espaços e tempos." Essas inovações constantes estão propiciando às novas gerações de sujeitos da aprendizagem a indução de novos estilos de vida mediados por extensões tecnológicas que auxiliam nos processos de acesso à informação, de armazenamento, intercâmbio, expressão e reelaboração criativa ou traduções intersemióticas de conteúdos em relação às imagens capturadas pelas telas digitais.

$\mathrm{Na}$ presente investigação, entende-se a tradução intersemiótica como uma prática crítico-criativa. Traduzir é codificar e desvendar os meios de produção e reprodução infinitas dos signos em outros signos, de um medium para outro medium, diferentes dos originais, como ressignificação, como potências em tramitação qualitativa e em devir, ou seja: "como pensamento em signos, como trânsito de sentidos, como transcriação de formas" (PLAZA, 2003, p. 14). Vale acrescentar que, por seu caráter de transmutação de signo em signo, 
qualquer pensamento é necessariamente uma tradução. Nesse cenário, o smartphone surge como protagonista na reconfiguração das práticas de produção, distribuição e exibição de conteúdos audiovisuais, como aponta Adriano Chagas em A imagem portátil: celulares $e$ audiovisual (2019):

Na contemporaneidade, a facilidade da câmera de vídeo do telefone celular também se apresenta à disposição dos indivíduos para uso profissional ou pessoal [...]. A própria atividade docente é protagonista dessa transformação. O conteúdo de suporte ao ensino está disponível em todo lugar, a qualquer momento, via aplicativos. Anotações em quadros-negros, lousas, flipcharts e todo tipo de projeção de apoio às aulas são instantaneamente capturadas pelas câmeras de telefones celulares dos alunos. As informações são transportadas para a memória do aparelho. (CHAGAS, 2019, p. 36).

A partir desse contexto e contaminada com a observação desses fenômenos em sua própria sala de aula ao ministrar a disciplina "Crítica de Dança", a autora do presente estudo pondera que, para participar desta nova estrutura social, os artistas-docentes em formação no mencionado curso da Unespar/FAP necessitam ter acesso e praticar uma nova alfabetização midiática, para que, quando em contato com seus alunos e alunas em espaços de ensino e aprendizagem das artes do corpo, também se envolvam com o vocabulário e a linguagem ali enfatizados pelos digital natives ${ }^{5}$ : a linguagem do corpo permeada pelas extensões digitais, as obras ou os discursos textuais videodançantes, como será mais bem explicitado na próxima sessão.

Pérez Gómez (2015) corrobora essa premissa ao destacar que aprender a linguagem das múltiplas telas atualmente chega a ser tão necessário quanto a alfabetização relacionada com a leitura e a escritura verbais. O autor afirma que "preparar os cidadãos [...] para que se envolvam com esse mundo compreendendo a natureza intrincada, conectada, da vida contemporânea, torna-se um imperativo ético e também uma necessidade técnica" (PÉREZ GÓMEZ, 2015, p. 21).

E sobre quais necessidades técnicas estaríamos a ponderar? Quais seriam as expectativas oriundas de sujeitos em formação na esfera de um curso superior em dança? Que atitudes poderiam ser adotadas para suprir as necessidades da chamada "pedagogia das mídias" (SANTAELLA, 2013, p. 125) em prol de uma aprendizagem dinâmica e ativa que produza modificações cognitivas, comportamentais e corporais? Que formas avaliativas poderiam ser geradas no âmbito da era das interações digitais conectivas?

A partir dessas questões norteadoras, buscaram-se embasamento e possíveis esclarecimentos nos escritos de Christopher Dede, sobretudo em Transforming Education for the 21st Century (2007) e Reconceptualizing Technology Integration to Meet the Necessity of Transformation (2011). O autor infere prognósticos que atestam a relevância de se pensar a formação docente em aderência com os pressupostos socioculturais contemporâneos, a partir dos quais os agentes em formação assimilem processos de construção, desconstrução e reconstrução permanente de conhecimentos. De acordo com Dede (2007; 2011), as novas gerações têm expectativas diferenciadas quanto aos conteúdos a serem apreendidos e aplicados em suas próprias formações. Para acadêmicos em formação no século XXI, teoria $\mathrm{e}(\mathrm{m})$ práxis pedagógica implicaria nos seguintes pontos: 1) liberdade maior para escolher 
disciplinas (optativas) e um espaço amplificado para expor suas opiniões e modos de pensar/ fazer as tarefas avaliativas propostas; 2) possibilidades amplificadas de interação advindas de propostas de tarefas coletivas; 3) possibilidade de inclusão no trabalho, de diversão (aplicativos?) e desafios na resolução de propostas; 4) multitarefas e hiperconectividade propostas por atividades interdisciplinares; 5) oportunidade para demonstrar estratégias de inovação e $(m)$ processos de criação.

Dede (2011) reforça a ideia de que as avançadas tecnologias de comunicação e as tecnologias da ubiquidade proporcionam um aprendizado "muito mais amplo e flexível [...] com ritmos personalizados e adaptados às necessidades individuais" (DEDE, 2011, p. 5). Trata-se da aprendizagem formulada pela pedagogia ubíqua que, em sua dimensão externa - aprendizagem como construção individual e social -, tem sido evidenciada historicamente pelo construtivismo sociocultural e em suas atualizações contemporâneas, dentre as quais se salienta o conectivismo postulado por George Siemens. Parte-se do princípio de que o estudo, a prática e/ou a fruição das artes são imprescindíveis tanto na formação sensível dos indivíduos, quanto na articulação comunicativa desses indivíduos no convívio social.

Como foco das reflexões aqui pretendidas, tomam-se as artes do corpo/dança em mediação tecnológica - videodanças - e seus processos de ensino-aprendizagem em cotejamento com a teoria de Vigotski (1896-1934), representante legítimo da visão históricocultural e autor de renome na área da Educação e da Psicologia, tendo contribuído de forma significativa para o avanço no conhecimento interdisciplinar. Na concepção histórico-cultural, o desenvolvimento da aprendizagem e a construção do conhecimento são o resultado das relações humanas e decorrem da convivência e produção da cultura, evidenciando que o conhecimento é socialmente construído.

Conforme aponta Edna Carvalho de Azevedo (2017, p. 11), "ao pontuar o vínculo da educação com a experiência estética, ele [Vigotski] abriu grande espaço para refletir sobre a educação e as artes." Partindo da leitura atenta acerca das considerações de Azevedo, é possível considerar que, embora a dança seja uma linguagem artística que utiliza predominantemente movimentos corporais para a sua realização, é na intencionalidade que a obra de arte decorrente do uso do corpo em interação com as tecnologias digitais - tradução intersemiótica ou movimentos videodançantes - expõe o caráter de utilização de corporeidades mais fluidas e da imagem em movimento do próprio movimento como meios e não como um fim. Isso possibilita uma abertura à investigação, que não se fixa na corporeidade presencial e carnalizada, embora não a ignore, pois se trata da arte da imagem do movimento.

A dança aqui problematizada é mediada por telas digitais e, como forma híbrida, rizomática e aberta é convertida em arte, tecnologia e comunicação.

Para Vigotski e seus leitores:

Sem conhecer a estrutura e o funcionamento dos complexos contextos locais e globais que rodeiam os indivíduos contemporâneos, não podemos entender a natureza dos seus esquemas de interpretação e atuação: os seus conhecimentos, crenças, hábitos, emoções, atitudes e valores. Assim, o mesmo ambiente ou contexto que cerca, condiciona, estimula e limita cada indivíduo, é, de 
certa forma, constituído e recriado, em vez de dado ou preestabelecido. [...] O aprendiz incorpora e adota progressivamente o conhecimento especializado e a cultura da comunidade, enquanto participa nas práticas sociais adultas, hoje, obviamente globais e, em grande parte, virtuais. (PÉREZ GÓMEZ, 2015, p. 49, grifo nosso).

Diante da inegável contribuição do pensamento vigotskiano à teoria do conhecimento e da aprendizagem, interessa sobremaneira pensar a pedagogia da ubiquidade digital em que, imersos na sociedade global da hiperconexão e da hipermobilidade, os sujeitos da aprendizagem são atravessados pelo contexto de suas aprendizagens. É a partir desse raciocínio que o conectivismo proposto por Siemens também ganha relevância e atualiza o coroláriochave da Teoria de Vigotski, ao integrar em seus estudos os pressupostos da teoria do caos, do pensamento complexo, das redes em multiconexões e dos sistemas auto-organizativos. Em Connectivism: a learning theory for the digital age (2005), o autor sustenta que a aprendizagem envolve a construção pessoal de conexões que podem ser sociais, presenciais ou virtuais.

Pérez Gómez (2015), por sua vez, resume em três tópicos elementares os oito princípios que regem as concepções teóricas da conectividade propostas por Siemens. São eles:

1) A relevância dos processos e dos contextos: sem ignorar os "conteúdos", o protagonismo do processo de aprendizagem desloca-se para conhecer, criar, aprender a aprender. A habilidade de "ver as conexões entre campos, ideias e modelos é essencial na era atual" (PÉREZ GÓMEZ, 2015, p. 50);

2) A importância da pluralidade e da qualidade das redes: a aprendizagem necessita do ambiente baseado em diferentes opiniões, propostas, perspectivas, olhares e intercâmbios, pois "a amplificação da aprendizagem, do conhecimento e da capacidade de compreensão e ação por meio do enriquecimento das redes é a síntese do conectivismo" (PÉREZ GÓMEZ, 2015, p. 51);

3) A importância decisiva da externalização da informação: trata-se da aprendizagem e da informação que atualmente pode ser armazenada, manipulada, transportada [via dispositivos móveis], pois se constituem em extensões do corpo e da mente humanos.

Permeando o contexto de ambientação do pequeno estudo de caso exploratório a ser discutido na próxima seção - a criação de videodanças a partir do uso de câmeras digitais acopladas aos smartphones como projeto avaliativo em uma disciplina formativa de artistasdocentes nas artes do corpo/dança -, é possível antecipar que os três tópicos anteriormente descritos, ao se referirem a postulados do conectivismo de Siemens, são aplicáveis e validados por meio da amostragem de 11 videodanças decorrentes da proposta de tradução intersemiótica.

O deslocamento da simples memorização de conteúdos teóricos, históricos, filosóficos e técnicos para a (re)criação de organizações audiovisuais complexas e híbridas, amalgamando conceitos e linguagens provenientes das artes do vídeo e da dança, confere complexidade à resolução de problemas de ordem sensível e estética. A disciplina "Crítica de Dança" se delineia eficazmente avaliada, desta forma, no atravessamento metodológico interdisciplinar aplicado em laboratórios na sala de aula, proporcionando aos sujeitos da aprendizagem um levantamento 
exaustivo de hipóteses, interrogações contínuas aos seus objetos/corpos em movimento, bem como à estrutura imagética e sonora elaboradas para os corpos em movimento. Em tal atitude avaliativa, emaranhada pelos fios da tecnologia digital, cada um dos futuros artistas-docentes se entretece como sujeitos socioculturais e protagonistas do ato de conhecer pelo criar, dançar, editar, videodançar e, assim, emancipar-se em novas corporeidades autônomas, como sugere Paulo Freire em sua Pedagogia da Autonomia: saberes necessários à prática educativa (1999). Nessa conjunção de saberes, encontram-se novas discursividades e subjetividades em devir, inseridas no contexto social dos pequenos coletivos formados em sala de aula.

O termo devir, neste artigo, coteja o conceito de devir para a filosofia de Gilles Deleuze (1997; 2011), ou seja, o movimento permanente que atua como regra, sendo capaz de criar e transformar tudo o que existe em seu próprio intervalo/processo de mudança constante. Deleuze afirma que não há nada para além da potência do devir. Assim, os seres e as coisas se afirmam em suas multiplicidades do real/verdade. O mundo emerge desse conceito e $(\mathrm{m})$ suas múltiplas potências: verdades abertas, qualitativas e em pleno devir. O devir deleuzeano situase nas frestas, nas brechas, nas aberturas rizomáticas de múltiplos sentidos.

Portanto, as mídias digitais e, dentre elas os smartphones, não podem mais ser consideradas como simples dispositivos de armazenamento de informação ou facilitadoras de comunicação e interação social. Essas mídias são legítimas extensões (in)orgânicas das corporeidades contemporâneas em devir e, como tal, enriquecem sentidos, subjetividades e as artes do corpo humano, que se constitui na "mídia primária dos processos de comunicação e dos textos culturais", como alerta Baitello Junior (2014, p. 12).

As relações peculiares entre a teoria e a prática na formação docente necessitam de uma atenção criteriosa para as transformações provocados pela pedagogia da ubiquidade. É neste sentido que Maurice Tardif argumenta em prol do exercício equilibrado e consciente entre a teoria e a práxis pedagógica na formação de professores, pois, ao assumirmos a premissa de que os futuros professores devem ser sujeitos ativos, "deveremos admitir que a prática deles não é somente um espaço de aplicação de saberes provenientes da teoria, mas também um espaço de produção de saberes específicos oriundos dessa mesma prática" (TARDIF, 2014, p. 234).

O raciocínio equivalente na presente investigação supõe que o trabalho dos futuros artistas-docentes das artes do corpo/dança deve ser considerado como um amplo espaço de criação, recriação, transformação, mobilização e tradução de/em novos saberes. Saberes esses eventualmente vinculados às mediações tecnológicas. Dessa forma, a sugestão de produção de textos videodançantes mediados por telas digitais como uma das formas de avaliação na disciplina "Crítica de Dança", objeto empírico da investigação, equivale à oportunidade de pensar o papel do artista-docente não desvinculado do pesquisador em arte e educação. Esta é a tese que encontra corroboração em Tardiff (2014, p. 235), ao afirmar que o docente, como sujeito criativo e (re)ativo, torna-se uma espécie de "ator que desenvolve e possui sempre teorias, conhecimentos e saberes de sua própria ação." Ação criativa, neste contexto, mediada pela tecnologia. 


\section{Educação e Metodologia de Pesquisa Qualitativa - Interdisciplinaridade e(m) Discussão}

A opção pela abordagem qualitativa nesta pesquisa em educação tem por justificativa o objetivo de enfatizar o fenômeno da linguagem e da percepção decorrente ou resultante do processo avaliativo na disciplina "Crítica de Dança", uma das disciplinas optativas da grade curricular do curso de Bacharelado e Licenciatura em Dança da (Unespar/FAP). Nesse tipo de abordagem metodológica, há a necessidade "do exercício da competência e da imaginação pelo pesquisador, num tipo de trabalho artesanal, não só como condição para o aprofundamento da análise, mas para a liberdade intelectual" (FAZENDA; TAVARES; GODOY, 2015, p. 62).

Bernadete Gatti e Marli André (2013), por sua vez, admitem que o foco desse tipo de investigação deve convergir para a compreensão dos possíveis e abertos significados atribuídos pelos sujeitos às suas intervenções sobre as ações ou os fenômenos a serem observados, descritos, analisados e interpretados. Como a autora do presente estudo encontra-se imersa no processo investigativo de atribuir sentidos à criação de artefatos físicos ou videodanças - resultantes de um processo avaliativo particular ancorado nas práticas educacionais e competências docentes exigidas pela era da ubiquidade -, a pesquisa qualitativa é a garantia da legitimidade metodológica para a validação das conclusões daí resultantes, visto que, no uso dessa metodologia, "busca-se a interpretação em lugar da mensuração, a descoberta em lugar da constatação [...] tornando-se inaceitável uma postura neutra do pesquisador" (GATTI; ANDRÉ, 2013, p. 30).

Os artefatos físicos mencionados tornam-se uma fonte de evidências do estudo de caso e, por consequência, da reflexão desenvolvida na investigação. Um artefato físico, segundo Robert K. Yin, é "um artefato cultural - um aparelho de alta tecnologia, uma ferramenta ou instrumento, uma obra de arte ou alguma evidência física do estudo" (YIN, 2001, p. 118, grifo nosso). As videodanças em pauta equivalem a um artefato artístico e cultural.

Para efeitos de esclarecimentos sobre o conceito de videodança adotado neste estudo, salienta-se que se trata de um produto híbrido na contemporaneidade, uma forma audiovisual dialógica que (re)pensa e (re)codifica a dança em uma plataforma midiática. Na videodança, "é a partir das diferenças que vídeo e dança dialogam, elaborando uma relação corpo-câmera que não é o simples registro, mas uma outra maneira de perceber o corpo, a imagem e o movimento" (CERBINO; MENDONÇA, 2012, p. 162-163). Assim, a dança, em sua extensão tecnológica, transforma o seu palco em tela.

Antes de se debruçar sobre a definição da amostragem, sobre a técnica de coleta de dados e sobre a discussão analítica dos artefatos físicos decorrentes, deve-se levar em consideração os componentes da situação avaliativa aqui proposta e fruto do estudo de caso exploratório em pauta. Destarte, neste momento da reflexão, torna-se crucial um esclarecimento sobre as interações e influências recíprocas que incidem sobre o objeto investigado, ou seja, o contexto 
institucional que o alberga e o define. Ao focalizar a disciplina "Crítica de Dança", entende-se que ela se caracteriza como uma amostragem da grade curricular de um dos cursos superiores de dança no Brasil. Inicia-se o percurso exploratório do objeto de pesquisa, portanto, a partir desse macro universo.

A história dos cursos superiores das artes do corpo/dança no país tem início somente em 1956. Segundo Eliana Rodrigues Silva (2016), a Escola de Dança da Universidade Federal da Bahia foi, durante vinte e nove anos, a única possibilidade de formação em dança na esfera universitária, enquanto Cristiane Wosniak (2017) acentua que foi somente na década de 1980 que outros três cursos superiores de dança foram implantados no Brasil. De acordo com Wosniak, o segundo curso foi criado em 1984, em Curitiba, na Pontifícia Universidade Católica do Paraná (PUC-PR), em convênio com a Fundação Teatro Guaíra (1984). Trata-se do curso de Bacharelado e Licenciatura em Dança que, desde 2011, encontra-se vinculado à Unespar/FAP. Ressalta-se que, desde a sua criação, o referido curso mantém a dupla habilitação simultânea, ainda em voga em algumas instituições de ensino superior no país: bacharelado e licenciatura, com duração de quatro anos, atuando na formação do artista-docente. E qual seria o papel diferencial desse profissional da educação com a dupla modalidade de formação? Isabel Marques, a arte-educadora que cunhou o termo em 1996 aplicando-o em sua tese de doutoramento, explica que o artista-docente seria aquele que não abandona as "possibilidades de criar, interpretar, dirigir e também tem como função e busca 'explícita' a educação em seu sentido mais amplo [...]a possibilidade de que processos de criação artística possam ser revistos e repensados como processos também 'explicitamente' educacionais" (MARQUES, 2015, p. 231).

As Diretrizes Curriculares Nacionais (DCNs) para os cursos de graduação em Dança do Conselho Nacional de Educação (CNE), aprovadas em 2004, compreendem a organização do projeto pedagógico, o perfil dos egressos, as competências e habilidades, os componentes curriculares, o estágio curricular supervisionado, as atividades complementares, o sistema de avaliação, a confecção do trabalho de conclusão de curso, o projeto de iniciação científica, o programa de iniciação à docência, quando houver, e outros aspectos relevantes do projeto pedagógico total, conforme as linhas e vocações contextuais específicas dos cursos em cada região brasileira. As diretrizes indicam as habilidades a serem desenvolvidas nos profissionais egressos dos cursos de graduação em dança no Brasil, destacando-se as seguintes: a) o domínio dos princípios cinesiológicos que se referem à performance corporal; b) o domínio da linguagem corporal; c) os desempenhos quanto à identificação, à descrição, à análise e à articulação dos elementos da composição coreográfica; d) o reconhecimento e a análise de estruturas metodológicas e didáticas na esfera do ensino da dança; e) habilidades para o trabalho da dança do portador de necessidades especiais, proporcionando a todos a prática dessa linguagem expressiva.

O curso da Unespar/FAP, atento às novas demandas da sociedade, implantou uma proposta de alteração curricular em 2017. O Projeto Pedagógico de Curso (PPC, 2017) ${ }^{6}$, 
elaborado pelo Núcleo Docente Estruturante (NDE) do curso, fundamenta-se na concepção de formação do artista-docente como um cidadão comprometido com possibilidades de atuação multidirecional, capaz de ampliar a inclusão social e o desenvolvimento humano. $O$ documento propõe a perspectiva de criação e ensino da dança, a noção de validação da diferença dos corpos e das danças, expandindo a ideia de formação "para" múltiplas danças e corpos, como um saber constituído a priori, para adotar a concepção de formação "com" múltiplos corpos e danças. Este entendimento de educação com/na diferença extrapola abordagens disciplinares de aprendizagem inclusiva e multicultural e implica na validação política de todos os corpos e suas danças, tanto nos procedimentos de ingresso no curso quanto no desenvolvimento da matriz curricular que constitui, em sua abordagem metodológica investigativa, a base filosófica de uma concepção de formação artístico-pedagógica inclusiva.

A articulação do binômio arte-educação, assumida na concepção da estrutura curricular, evidencia as especificidades e as complementaridades da licenciatura e do bacharelado em Dança, apoiadas na noção sistêmica de complexidade de produção de conhecimento, implícita no abandono do entendimento cartesiano de linearidade de junção das partes com finalidade de conhecimento do todo, problematizando o binômio Arte-Educação. O referido PPC foi aprovado em dezembro de 2017, implantado em 2018 e encontra-se atualmente em vigor.

É diante do contexto histórico-institucional acima exposto que a disciplina "Crítica de Dança" pode assumir, nesse momento da reflexão, o epicentro do debate para introduzir as questões inerentes à autonomia da educação na/para a era digital.

De acordo com o plano de ensino da referida disciplina, referente ao ano de 2018, observa-se que a ementa prevê a "análise de diferentes modos de construção da crítica em dança" (PLANO DE ENSINO, 2018, p. 1). Trata-se de uma disciplina semestral constituída por 68 horas distribuídas entre atividades teóricas e práticas. São cinco os objetivos elencados no referido plano, a saber: 1) discutir o corpo e a dança sob enfoques plurais a partir de reflexões e análises textuais (escritas e audiovisuais); 2) produzir textos analíticos e críticos acerca de diferentes hipóteses e configurações de/em dança na contemporaneidade; 3) traduzir intersemioticamente possibilidades de danças-textos $\mathrm{e}(\mathrm{m})$ textos de dança; 4) identificar o papel da crítica em dança na contemporaneidade a partir de reflexões e ramificações geradas pela obra/performance/espetáculo; 5) criar estratégias de leitura e produção textual em variados suportes midiáticos: corpografias, meios digitais/blogs, sites, mídias sociais e jornalismo cultural. O processo avaliativo em pauta deu-se na confluência da totalidade dos objetivos propostos.

E de que forma se deu a definição da amostragem dos artefatos físicos nessa investigação? A amostragem, composta por 11 videodanças elaboradas pelos trinta e nove alunos e alunas regularmente matriculados, foi constituída pela totalidade dos produtos elaborados em consequência avaliativa da própria disciplina.

Uma das atividades/tarefas extraclasse designadas aos acadêmicos consistiu em realizar uma visita guiada a uma exposição de gravuras em um espaço expositivo da cidade de Curitiba - o Museu de Arte da UFPR7 (vide Figura 1). A exposição do artista contemporâneo polonês 
Pawel Kwiatkowski, denominada Onda ${ }^{8}$, interessou à ministrante da disciplina por tratar de questões em debate na esfera da disciplina, tais como: o corpo em trânsito na urbe; a solidão do indivíduo contemporâneo; as conexões e interações de um corpo só em meio à multidão. Segundo Kwiatkowski, "o fluxo dos transeuntes, aliado à tentativa de desenvolver um modelo iconográfico de homem moderno inserido no contexto existencial da realidade de hoje, tornaram-se uma fonte de inspiração constante" (KWIATKOWSKI, 2018).

Figura 1 - Visita a um espaço expositivo para coleta de dados (registros de gestos e movimentos)
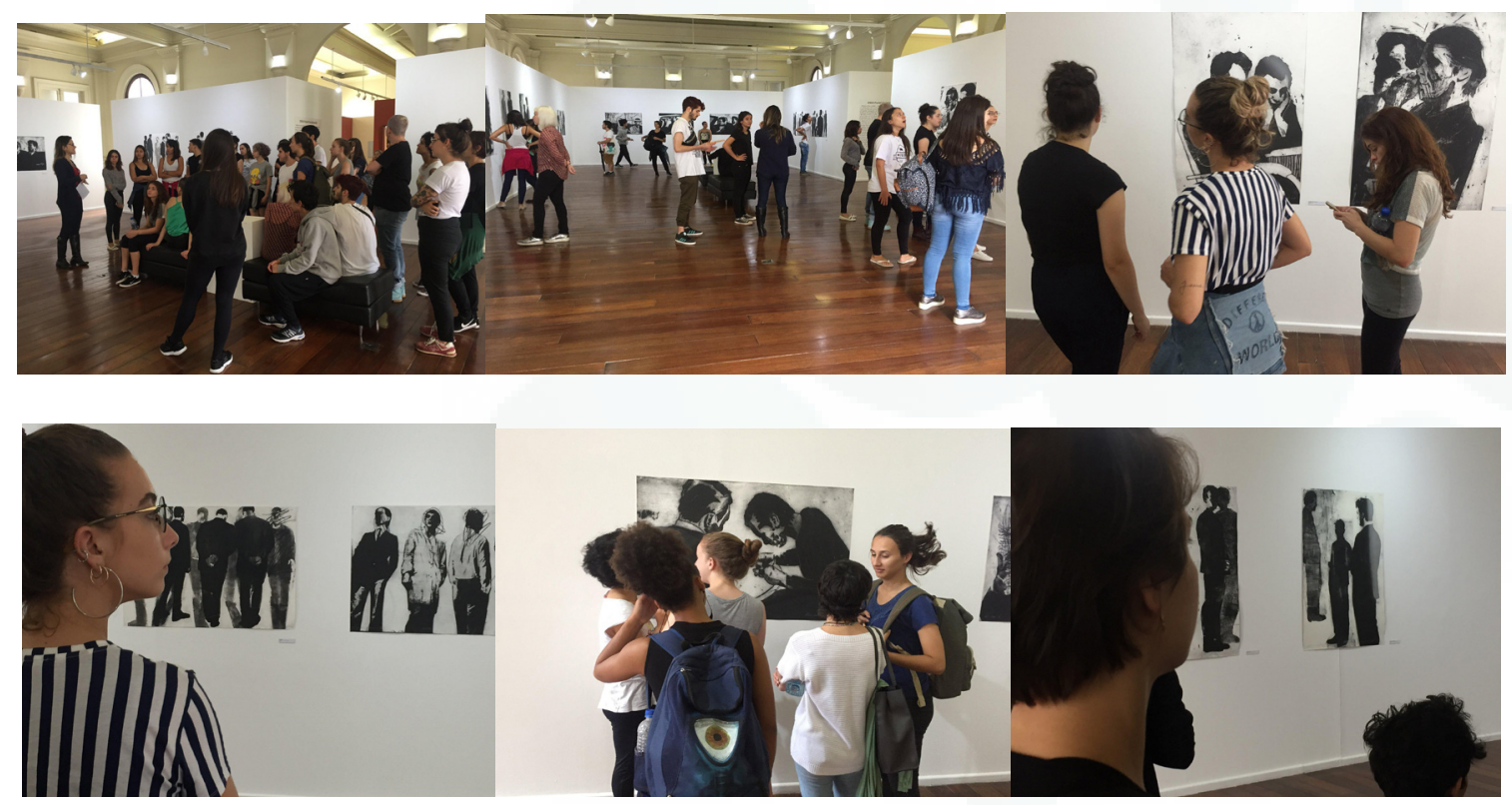

Fonte: Mosaico de imagens fotográficas do acervo da autora, publicadas na plataforma digital Facebook).

Quando da visita guiada ao espaço expositivo, no mês de março de 2018, os acadêmicos foram instruídos a observar a série de quadros com as gravuras em técnicas gráficas combinadas - em preto e branco -, ouvir a explanação da museóloga sobre as obras, anotar detalhes de movimentos, desenhos, corpos e depois se reunir nos grupos predefinidos em sala de aula, por escolha dos próprios alunos. Cada grupo deveria registrar as imagens - fotografias e vídeos - que mais lhes chamassem a atenção, por critérios discutidos na esfera grupal, utilizando as câmeras de seus smartphones. Vários enquadramentos, distâncias e perspectivas das gravuras deveriam ser documentadas para se ter um material de coleta básico a ser trabalhado na próxima etapa da avaliação: a criação dos roteiros de videodanças pautados nas ideias sobre o(s) sujeito(s) contemporâneo(s) e urbano(s). Os gestos e os movimentos oriundos das gravuras deveriam ser assimilados pelos seus próprios corpos - memória performática -, pois a museóloga fora informada da possibilidade de os alunos se moverem/dançarem no espaço expositivo. A visitação ao museu durou cerca de duas horas.

A etapa seguinte na constituição da amostragem de videodanças compreendeu o período posterior à visitação do museu, na qual os grupos já constituídos aproveitavam os espaços e os tempos proporcionados na esfera da disciplina para debater, construir e 
elaborar suas videodanças. Dois laboratórios práticos específicos foram proporcionados ao alunos, mediante o convite feito a dois egressos de cursos da Unespar/FAP e especialistas em videodanças: uma artista oriunda do curso de dança e um videoartista oriundo do Bacharelado em Cinema e Audiovisual. Nessas ocasiões, ambos mostraram à turma diversas possibilidades do pensar-fazer videodança.

Nas aulas de reflexão teórica acerca da linguagem da videodança, colocavam-se também critérios balizadores para a construção dos textos audiovisuais, a saber: 1) as imagens deveriam receber um tratamento de cor nas tonalidades preto e branco, respeitando a estética das composições gráficas vistas na exposição do artista polonês; 2) as gravuras e sua temática - o urbano, o movimento, o trânsito, o universo contemporâneo - deveriam se constituir como mote para o processo de criação de movimentos dançantes transpostos para a linguagem audiovisual; 3) as questões periféricas e de interesse de linguagem estética e tratamento audiovisual - traduções intersemióticas - deveriam ser livres e focadas nas discussões, opções e escolhas dos integrantes de cada grupo; 4) ao menos um dos integrantes do grupo deveria tomar parte ativa - performar em meio à urbe - e estas imagens se constituíram no assunto a ser (re)formulado em linguagem audiovisual; 5) quanto ao tratamento sonoro, seria de livre estilo e escolha do grupo, desde que as composições fossem originais, para garantir a exibição pública em espaços e plataformas digitais.

Salienta-se que o processo total de construção das videodanças, desde a visitação ao museu, em março, até o momento da apresentação pública, durou cerca de três meses, culminando com mostra avaliativa das obras no auditório da própria instituição, no dia 20 de junho de 2018, das 09h00 às 12 h00.

As questões que permearam o processo avaliativo foram as seguintes: 1) De que modo e com que meios o contexto sociocultural em que os integrantes de cada grupo encontram-se imersos viriam à tona, ou não, em suas abordagens audiovisuais dançantes? 2) De que forma os artefatos - smartphones - seriam determinantes nos processos de organização, seleção e ação criativa das videodanças? 3) O próprio contexto da era digital ubíqua em suas múltiplas conexões seria tematizado em alguma das videoperformances? 4) Que tipo de produtos artísticos codificados resultariam de uma experiência de aprendizagem ubíqua extrapolando o sensível e o estético a partir das mediações tecnológicas? 5) Seria possível decodificar os códigos trabalhados nestes textos audiovisuais? 6) Como os artistas-docentes em formação lidariam com o vocabulário híbrido das novas mídias em processos de tradução intersemiótica, reconduzindo as gravuras visitadas no museu e os seus próprios corpos em movimento em meio à urbe na passagem de uma mídia à outra?

A partir do exposto, foi possível avaliar a totalidade de 11 artefatos físicos resultantes dos trabalhos audiovisuais dançantes, dos quais participaram 39 alunos e alunas em alguma das funções inerentes a este processo de criação (performance, captação de imagens, roteiro, edição, produção), sendo que a totalidade das videodanças (vide Quadro 1) se constituiu em material de estudo e reflexão, e nenhuma delas tendo sido descartada. 


\section{Quadro 1 - Amostragem das videodanças}

\begin{tabular}{|c|c|c|}
\hline TÍTULO/VIDEODANÇA & ROTEIRO/IDEIA/CONSTRUÇÃO & EQUIPE \\
\hline CEGUEIRA SELETIVA & $\begin{array}{l}\text { "Entre conceitos e sensações, eis uma } \\
\text { expressão artística do urbano..." }\end{array}$ & $\begin{array}{l}03 \text { alunos } \\
\text { se revezaram na captura, no } \\
\text { tratamento e na edição }\end{array}$ \\
\hline HANDY & $\begin{array}{l}\text { "Através do meu teclado digito. } \\
\text { Através da sua tela você lê. } \\
\text { Aqui criamos um elo de comunicação." }\end{array}$ & $\begin{array}{l}03 \text { alunos } \\
\text { se revezaram na captura, no } \\
\text { tratamento e na edição }\end{array}$ \\
\hline CANCERIANA À PROCURA & $\begin{array}{l}\text { "Canceriana, morena alta, charmosa, } \\
\text { vaidosa, cabelos sedosos, pele aveluda- } \\
\text { da. Sem vícios, comunicativa, extrover- } \\
\text { tida, sentimental, à procura..." }\end{array}$ & $\begin{array}{l}04 \text { alunos } \\
\text { se revezaram na captura, no } \\
\text { tratamento e na edição }\end{array}$ \\
\hline $\begin{array}{l}\text { APARTAMENTO DE MÁR- } \\
\text { MORE }\end{array}$ & $\begin{array}{l}\text { "Esculturas que perpetuam assimilações } \\
\text { da fragilidade e do caráter disfórico da } \\
\text { existência. Talvez a morte não seja mais } \\
\text { surreal que a vida..." }\end{array}$ & $\begin{array}{l}04 \text { alunos } \\
\text { se revezaram na captura, no } \\
\text { tratamento e na edição }\end{array}$ \\
\hline A PRINCÍPIO, SEM TÍTULO & $\begin{array}{l}\text { "Das imprevisibilidades de um cotidiano } \\
\text { urbano cujas ocorrências são frutos de } \\
\text { uma contextualidade espontânea." }\end{array}$ & $\begin{array}{l}05 \text { alunos } \\
\text { se revezaram na captura de } \\
\text { imagem e convidaram um co- } \\
\text { lega do curso para a edição }\end{array}$ \\
\hline ÉDEN & "GÊNESIS, 2 7-8" & $\begin{array}{l}05 \text { alunos } \\
\text { se revezaram na captura de } \\
\text { imagem e convidaram um } \\
\text { colega do curso para suportes } \\
\text { técnicos de ferramentas de } \\
\text { edição }\end{array}$ \\
\hline CONEXÕES CONECTADAS & $\begin{array}{l}\text { "Qual é a brecha que existe entre o real } \\
\text { e o virtual? Em um mundo conectado, a } \\
\text { realidade é compartilhada e curtida com } \\
\text { um toque de um dedo. Dedos foram su- } \\
\text { perestimados, enquanto olhos nos olhos, } \\
\text { a cegueira se fez. Então te pergunto, } \\
\text { como você se conecta com o mundo?" }\end{array}$ & $\begin{array}{l}06 \text { alunos } \\
\text { se revezaram na coreografia e } \\
\text { no roteiro e convidaram três } \\
\text { colegas para gravação e edição }\end{array}$ \\
\hline (EM)MOÇÃO & $\begin{array}{l}\text { "Interação imagética que abomina a } \\
\text { linearidade. Breves histórias que são } \\
\text { em nós, algo além do que são em } \\
\text { outro, algo além do que são (em) } \\
\text { moções." }\end{array}$ & $\begin{array}{l}01 \text { aluno } \\
\text { responsável pelo roteiro, } \\
\text { pela gravação e pela edição } \\
\text { audiovisual, convidando os } \\
\text { integrantes e seu grupo de } \\
\text { dança [comunidade externa] } \\
\text { para performar }\end{array}$ \\
\hline ANFÊMERO & $\begin{array}{l}\text { "como vivemos cegos na rotina do } \\
\text { dia-a-dia, apenas existindo no modo } \\
\text { automático de viver e ver a vida..." }\end{array}$ & $\begin{array}{l}03 \text { alunos } \\
\text { se revezaram na coreogra- } \\
\text { fia, no roteiro e na gravação, } \\
\text { convidando } 1 \text { colega para a } \\
\text { edição final }\end{array}$ \\
\hline PASSAGEM & $\begin{array}{l}\text { "O urbano que se movimenta. Vem e } \\
\text { vai. Sai. Fica. Sai. Urbano de gente que } \\
\text { se encontra, que deixa, que junta, que é } \\
\text { só. Tempo. Move." }\end{array}$ & $\begin{array}{l}04 \text { alunos } \\
\text { se revezaram na coreogra- } \\
\text { fia, no roteiro e na gravação, } \\
\text { convidando um colega para a } \\
\text { produção }\end{array}$ \\
\hline EFÊMERA & $\begin{array}{l}\text { "As angústias: reflexão como enfrenta- } \\
\text { mento do eu: a possibilidade de reden- } \\
\text { ção pelo homem moderno ora percebido } \\
\text { como observador, ora observante..." }\end{array}$ & $\begin{array}{l}01 \text { aluna } \\
\text { responsável pelo roteiro e } \\
\text { pela performance, convidando } \\
\text { três colegas para gravação e } \\
\text { edição }\end{array}$ \\
\hline
\end{tabular}


Trazendo para o processo de avaliação dos artefatos físicos breves aportes da análise de conteúdo desenvolvida por Laurence Bardin $(2002)^{9}$, é possível decodificar e extrair palavraschave ou o conteúdo dessas 11 videodanças, tratadas, cada uma delas, como "documento ou unidade de gênero" (BARDIN, 2002, p. 107).

A partir do pressuposto de que cada um dos textos audiovisuais elencados no Quadro 1 contém códigos inerentes das imagens e das paisagens sonoras, sentidos e significados em devir e que podem ser expostos de forma clara, objetiva ou também subjetiva, é realizada a análise de conteúdo dessa amostragem de textos audiovisuais em um entendimento interdisciplinar. Trata-se de um procedimento que "pode ser utilizado para se captar o sentido subliminar subjacente ou subjetivo de um texto. Neste caso, em vez de quantificar, é possível levantar hipóteses, inferências e interpretações sobre o material" (FAZENDA; TAVARES; GODOY, 2015, p. 111).

Assim, as 11 unidades de gênero ou instrumentos físicos são reunidas em torno de três eixos sobre a relação entre o "corpo" e uma outra categoria de análise de ocorrência temática, inferida a partir das palavras-chave descritas no roteiro sintético ou release da obra, somadas à interpretação da organização estética audiovisual:

EIXO 1 - corpo e contexto da era digital ubíqua em suas múltiplas conexões tematizados nas videodanças performáticas. Nessa categoria, houve a ocorrência de três videodanças que tematizaram conexões por meio de celulares e aplicativos. Das palavras-chave dos trabalhos, destacam-se: HANDY (teclado; digitar; elo; tela; comunicação); ANFÊMERO (modo automático; dia a dia); CONEXÕES CONECTADAS (virtual; mundo conectado; realidade compartilhada; toque; mundo);

EIXO 2 - corpo e contexto sociocultural dos integrantes de cada grupo - o trânsito e a mobilidade dos corpos na cidade que os abriga - tematizados nas videodanças performáticas. Nessa categoria, houve a ocorrência de seis videodanças que tematizaram o espaço urbano, o trânsito dos corpos em movimento, as questões sociais, o sentir-se só em meio à multidão. Das palavras-chave dos trabalhos, destacam-se: PASSAGEM (urbano; vem e vai; gente; tempo; move); CEGUEIRA SELETIVA (urbano; expressões; sensações); EFÊMERA (homem moderno; observador; observante); A PRINCÍPIO, SEM TÍTULO (cotidiano; urbano; imprevisibilidade); CANCERIANA À PROCURA (procura; extrovertida); APARTAMENTO DE MÁRMORE (existência; vida);

EIXO 3 - corpo virtual em reelaboração e manipulação do material gravado pela linguagem digital/vocabulário midiático em tradução intersemiótica. Nessa categoria, houve a ocorrência de duas videodanças que tematizaram a fragmentação do corpo humano e o expuseram a narrativas permeadas à intensa manipulação de imagens. Das palavras-chave dos trabalhos, destacam-se: (EM)MOÇÃO (linearidade; breves histórias; nós); ÉDEN (gênesis).

A discussão dos instrumentos físicos decorrentes das três categorias discriminadas deve estar vinculada aos seus elementos componentes, imagéticos e sonoros, considerando-se tanto o conteúdo em devir ou latente, quanto o factualmente manifestado na materialidade dos textos audiovisuais. 
As videodanças da categoria 1 (vide Figura 2) trazem o smartphone como protagonista nas ações performáticas levadas a termo na tela. Os corpos-usuários se locomovem em espaços urbanos abertos ou fechados com o foco visual sempre centrado no aparelho digital. Parecem querer problematizar as mediações simbólicas do sujeito contemporâneo que se converte irreversivelmente na figura do phoneur em substituição à figura simbólica do flâneur, como adverte Chagas (2019).

Figura 2 - Videodanças da categoria corpo em conexão - era digital ubíqua
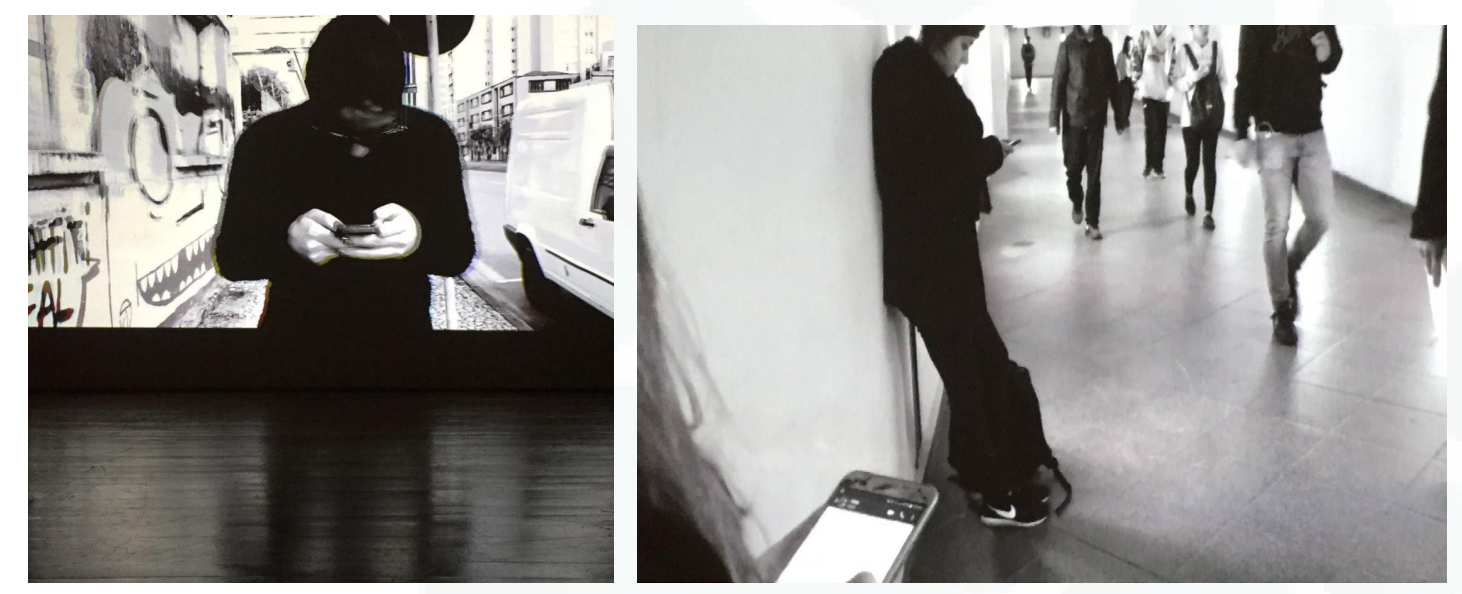

Fonte: Mosaico de imagens fotográficas do acervo da autora - publicadas na plataforma digital Facebook.

No entanto, este possível phoneur é o novo personagem contemporâneo da era da ubiquidade, visto que, sempre conectado, "também circula pela cidade, como seu oposto, mas agora com a mediação do telefone celular" (CHAGAS, 2019, p. 89). As relações com as gravuras do artista polonês - origem do processo de tradução intersemiótica - são evidentes e aqui atualizadas para as plataformas digitais. A câmera dos aparelhos móveis foram usadas de forma ordinária, como uma câmera testemunha das ações dos usuários consumindo imagens em seus celulares. Poucos movimentos de câmera foram utilizados e quando surgiram foram transições suaves.

As videodanças da categoria 2 (Figura 3) trazem o espaço urbano como protagonista nas ações performáticas levadas a termo na tela. Os corpos-sujeitos performam caminhadas apressadas avançando para a câmera, entendida aqui também como testemunha do ato performativo. Em A Princípio, Sem Título, por exemplo, os integrantes do grupo são adeptos das danças de rua (hip-hop) em suas manifestações diversas e, na obra videodançante, performaram no lugar de seu discurso/ensaio - no alto de um edifício - olhando para a cidade que os instiga. Ações e $(m)$ movimento deram preferência para solistas ao invés de grandes aglomerados de pessoas em frente à câmera. As imagens são acompanhadas de trilhas especialmente compostas para o material imagético em trabalhos colaborativos e interdisciplinares. As edições são predominantemente em planos-sequências com poucos cortes e, quando estes acontecem, são em decorrência do ritmo musical que se altera. 
Figura 3 - Videodanças da categoria corpo em contexto sociocultural - espaço urbano
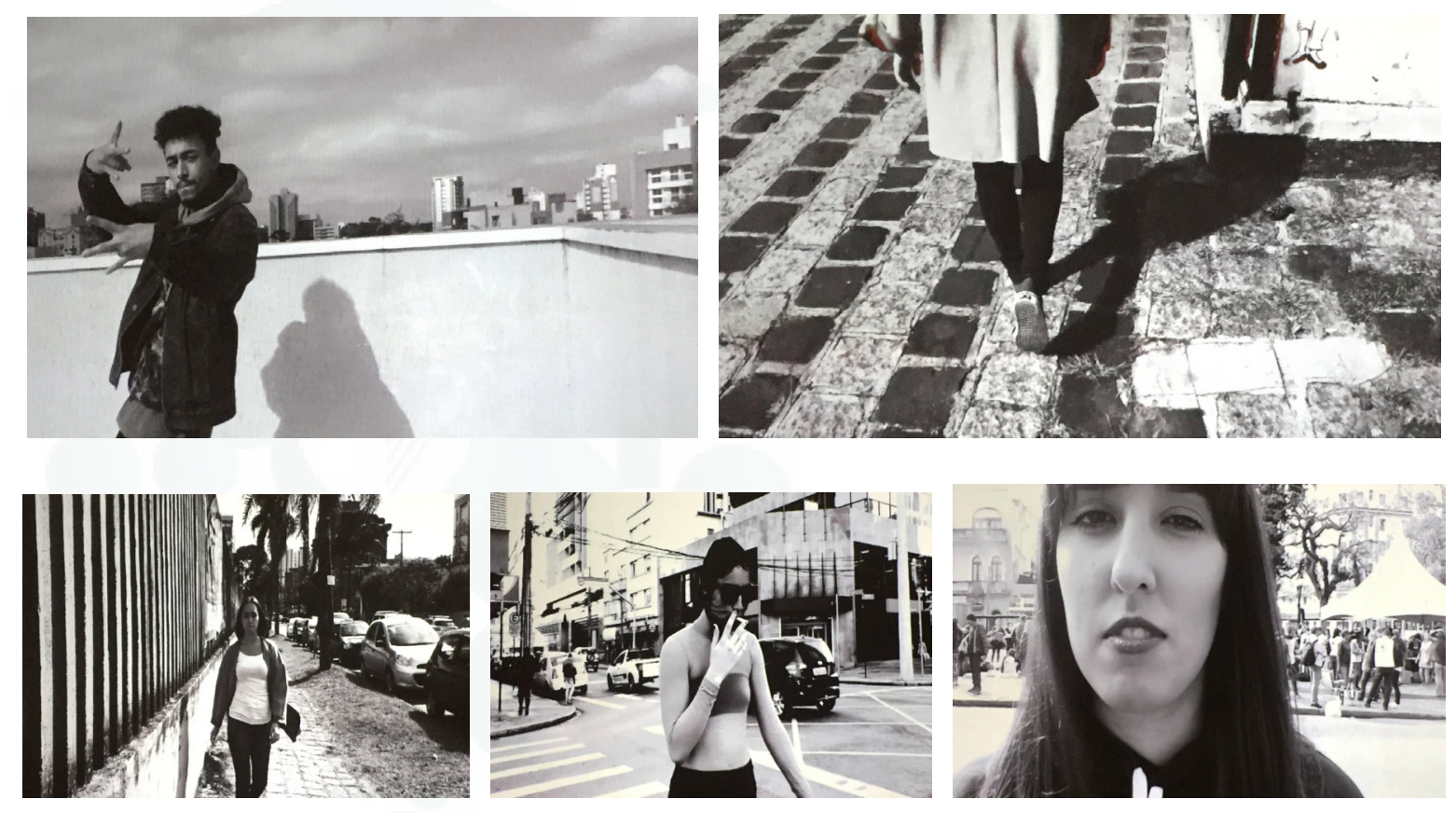

Fonte: Mosaico de imagens fotográficas do acervo da autora - publicadas na plataforma digital Facebook.

As videodanças da categoria 3 (vide Figura 4) trazem o próprio vocabulário das mídias digitais na conversão e na tradução dos corpos dançantes. Os corpos-sujeitos nessas obras são manipulados numericamente, fracionados, (des)articulados em novas corporeidades digitais, como requerem os pressupostos de uma era permeada pelas tecnologias ubíquas. Como adverte Pérez Gómes, as novas gerações - incluindo-se aqui os alunos integrantes desses grupos produtores das videodanças da categoria 3, notadamente os mais jovens da turma ou nativos digitais - se "convertem, em certa medida, em produtoras de conteúdo, comunicadoras de sucessos e experiências, usando a palavra, a imagem, o movimento, o hipertexto..." (PÉREZ GOMES, 2015, p. 27). Nestes casos, as obras ainda passaram por um processo de finalização, optando por adotar uma série de manipulações e interferências tecnológicas advindas dos recursos e dos aplicativos acoplados aos dispositivos móveis mais modernos.

Figura 4 - Videodanças da categoria (des)corporeidades digitais - manipulações
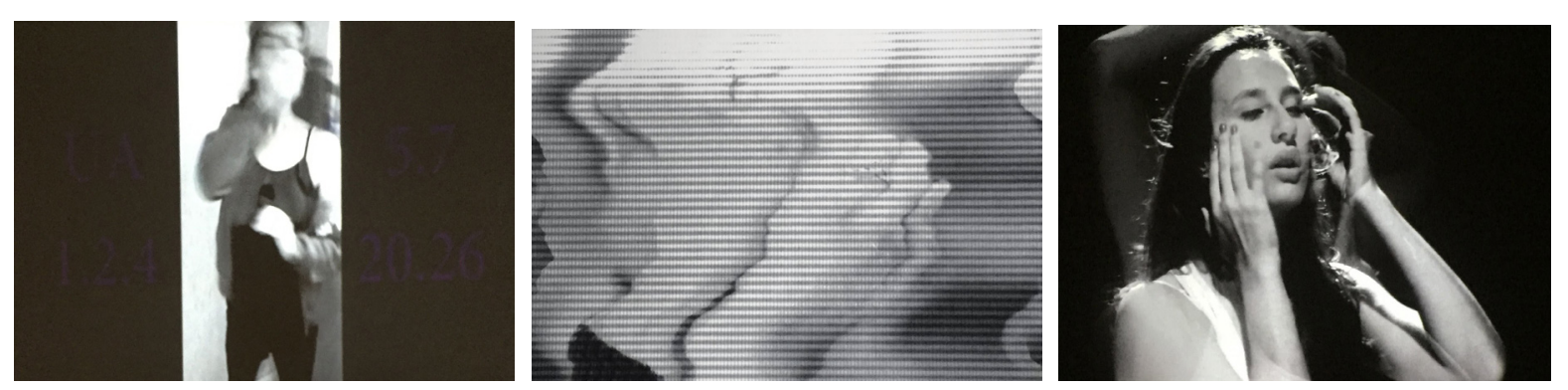

Fonte: Mosaico de imagens fotográficas do acervo da autora - publicadas na plataforma digital Facebook. 
Nas obras representativas dessa categoria específica, admite-se que o uso integrado/ acoplado da tecnologia é a continuação da evolução corporal por outros meios, e implica uma transcendência dos materiais e da informação utilizada para um fim determinado, a comunicação. É o que corrobora Raymond Kurzweil com a premissa de que "todas as artes compartilham o mesmo objetivo: comunicação entre o artista e o público" (KURZWEIL, 2007, p. 37).

Desta forma, percebe-se o quanto Marshall McLuhan (1989) é ainda atual, ao teorizar sobre os meios de comunicação como extensões do ser humano, ou seja, por antecipar discussões que giram em torno da crescente legislação das pedagogias da ubiquidade que se lançam rumo às novas corporeidades dançantes em espaços e tempos de (des)articulação digital, como uma ampliação em devir no âmbito da comunicação, da arte e da cibercultura. Essas imbricações tecnológicas, sensíveis e estáticas - tecnoestéticas - "modificaram de forma contundente o cenário da dança tecnologizada, e este fenômeno não é atemporal: a complexidade do mundo atual é responsável pelo surgimento destas tecnologias, ao mesmo tempo, que é fruto delas" (WOSNIAK, 2013, p. 46-47).

Ao fazerem uso das novas mídias, os artistas-docentes em formação, nesse estudo de caso, acabam por expandir o campo da educação, das artes e das comunicações rumo ao território das interfaces tecnológicas. Merece destaque o fato de que estes acadêmicos têm continuamente consumido, processado e criado informações digitais e, por meio de suas multiconexões em tecido social digital, têm partilhado esses conteúdos - instrumentos físicos ou videodanças - em redes sociais como o Facebook e plataformas digitais de armazenamento como Vimeo e YouTube, além de consumirem as obras audiovisuais diretamente nas telas de seus smartphones. O próprio dispositivo, nesse caso, converte-se em medium e processo, ferramenta e ato de criação. E, nessa paisagem virtual, os corpos contemporâneos e conectivos vêm dançar nos palcos de múltiplas telas.

\section{Considerações Finais}

O percurso deste artigo passou por uma reflexão sobre práticas educacionais, ancoradas nas competências docentes exigidas pela era da ubiquidade, inseridas no âmbito do curso de formação de artistas-docentes de dança em uma instituição pública de ensino superior no Paraná (Unespar/FAP). O objeto empírico da investigação foi constituído por um singular processo avaliativo na disciplina "Crítica de Dança", que integra a grade curricular do referido curso.

A partir dos pressupostos de uma pesquisa qualitativa com abordagem metodológica de revisão bibliográfica associada a um estudo de caso do tipo exploratório, foi possível realizar uma breve discussão da amostragem de onze instrumentos físicos decorrentes dos trabalhos elaborados por trinta e nove alunos e alunas matriculados na referida disciplina, ancorando a discussão nas bases teóricas de autores vinculados à grande área da Educação, tais como de Vigotski, Siemens, Pérez Gómez e Dede. Por se tratar de uma pesquisa situada no devir e 
nas frestas conectivas da interdisciplinaridade, a utilização das noções de educação ubíqua advindas das convergências dos campos das artes e das comunicações também se tornou vital à proposta deste estudo reflexivo e exploratório.

Ao longo do presente estudo, foi possível evidenciar a eclosão de novas corporeidades dançantes que emergem em espaços e tempos de (des)articulação digital, utilizando como parâmetro discursivo a criação de videodanças, elaboradas pelos alunos, recorrendo-se aos seus próprios smartphones e disponibilizadas nas redes sociais e plataformas digitais. Ressaltase que o texto imagético em diálogo com o texto verbal foi aqui decorrente dos registros fotográficos constantes no acervo da autora desta investigação, todos eles disponibilizados nas redes sociais e compartilhados pelos sujeitos da aprendizagem, os artistas-docentes em formação, em concordância com este procedimento.

Dentre as inferências resultantes da abordagem de análise de conteúdo do universo da amostragem, foi possível deduzir que o projeto avaliativo alternativo levado a termo na disciplina crítica de dança, estando descentralizado de ações meramente fundadas em aspectos de codificação e memorização de conteúdos, facilitou a aprendizagem e a fixação de conteúdos pelo pensar-fazer arte por meio do corpo em mediação tecnológica.

A relevância dos contextos socioculturais dos integrantes dos grupos formados em sala de aula, em aderência com os aspectos do conhecer, aprender, criar, recriar e aprender a aprender, ganhou contornos passíveis de serem vislumbrados no processo de criação e apresentação dos produtos finais.

Ao elencarmos novamente as questões norteadoras da investigação - Quais seriam as expectativas oriundas de sujeitos em formação na esfera de um curso superior em dança? Que atitudes poderiam ser adotadas para suprir as necessidades da chamada pedagogia das mídias em prol de uma aprendizagem dinâmica e ativa que produza modificações cognitivas, comportamentais e corporais? E que formas avaliativas poderiam ser geradas no âmbito da era das interações digitais conectivas? -, foi possível verificar que a amplificação das redes de acesso a materiais, a observação do entorno social, a visita ao espaço expositivo, a fruição estética de códigos de uma área como as artes visuais e suas gravuras de/sobre o movimento em meio à metrópole, com a oportunidade de refletir sobre as conexões interdisciplinares e sobre os modos de ação e criação de traduções do corpo de uma mídia para a outra, possibilitaram uma aprendizagem calcada em diferentes perspectivas do conhecimento.

Retomando os postulados de Dede e suas hipóteses concernentes às expectativas das novas gerações quanto aos conteúdos a serem apreendidos e aplicados em suas próprias formações no ensino superior, é possível deduzir que, para os artistas-docentes em formação, a teoria ou o conteúdo da disciplina "Crítica de Dança", por exemplo, foi (re)conectado à práxis pedagógica, implicando no aumento considerável de um espaço fluido para expor suas opiniões e modos de pensar/fazer as tarefas avaliativas propostas. Também é válido mencionar as possibilidades amplificadas de interação advindas da proposta avaliativa coletiva. Quanto à possibilidade de (re)aproveitamento do universo e do vocabulário digitais, o uso de 
smartphones e aplicativos na realização da tarefa criativa ampliou e diversificou os possíveis desafios na resolução da proposta. As multitarefas de tradução intersemiótica, facilitadas pela hiperconectividade com seus aparelhos móveis, transpôs a atividade pedagógica avaliativa para o campo interdisciplinar e, diante do exposto, foi possível admitir que todos os trinta e nove alunos e alunas tiveram resguardadas a oportunidade de demonstrar estratégias de inovação e $(m)$ processos de criação.

Vale destacar que o olhar crítico dos grupos para os trabalhos dos colegas, no dia da exibição pública das videodanças, demonstrou a variedade de possibilidades de bases e acessos às interfaces digitais, síntese do conectivismo postulado por Siemens, a partir de Vigotski.

$\mathrm{Na}$ condução do projeto avaliativo, os trabalhos foram externalizados em várias fontes midiáticas. As fotografias do processo de criação, da visita ao museu, dos ensaios e apresentação pública foram postadas nas redes sociais com muitos retornos de comentários e curtidas/likes. Os instrumentos físicos em si - as videodanças - foram divulgados não apenas nas redes sociais coletivas e individuais - Facebook e Instagram -, mas também houve um desejo e um esforço coletivo na disponibilização dos materiais audiovisuais nas plataformas de arquivos digitais, como o Vimeo e o YouTube, para serem consumidas em dispositivos periféricos como tablets, laptops, computadores e nas próprias telas dos smartphones.

O estudo explorou, portanto, uma possibilidade de aprendizagem e avaliação ubíquas, na qual foi possível constatar que a onipresença da informação como entorno simbólico de nossas redes de socialização interferem também na ubiquidade da aprendizagem, afetando, desta maneira, as próprias práticas educativas em ambientes de ensino formal.

Como resultado prático e quantificável, além da produção das 11 videodanças, também foi possível concluir que as mediações tecnológicas ubíquas alteram as maneiras como nos relacionamos com as artes do corpo, que, por sua vez, amplificam a linguagem da dança pela contaminação das múltiplas telas digitais.

O exercício da prática pedagógica e avaliativa alicerçada pelos smartphones nessa situação acabou por evidenciar que a informação atualmente armazenada, manipulada, transportada [via dispositivos móveis periféricos], constitui-se em extensões do corpo e da mente humanos e que se reconfiguram irreversivelmente em novas corporeidades dançantes que emergem no século XXI em espaços e tempos de (des)articulação digital.

\section{Referências}

AZEVEDO, E. C. de. Arte da dança e tendências contemporâneas do balé: projeções na educação. Brasília. Tese de Doutorado. Programa de Pós-Graduação em Educação da Faculdade de Educação da Universidade de Brasília, 2017.

BAITELLO JUNIOR, N. A era da iconografia: reflexões sobre a imagem, comunicação, mídia e cultura. São Paulo: Paulus, 2014.

BARDIN, Laurence. Análise de conteúdo. Lisboa: Ed. 70, 2002. 
CHAGAS, A. A imagem portátil: celulares e audiovisual. Curitiba: Appris, 2019.

CERBINO, B.; MENDONÇA, L. Coreografia, corpo e vídeo: apontamentos para uma discussão. In: CALDAS, P. et al. (Org.). Dança em foco - ensaios contemporâneos de videodança. Rio de Janeiro: Aeroplano, 2012, p. 151-166.

CONSELHO NACIONAL DE EDUCAÇÃO. Diretrizes Curriculares Nacionais para os cursos de graduação em dança. Resolução n 3, de 8 de março de 2004. Disponível em: <http://portal. mec.gov.br/cne/arquivos/pdf/CES03-04.pdf>. Acesso em: 21 dez. 2019.

DEDE, C. Transforming education for the 21st century. Cambridge: Harvard Education, 2007. Disponível em: <http://citeseerx.ist.psu.edu/viewdoc/download? doi=10.1.1.462.7531\& rep $=$ rep1\&type $=p d f>$. Acesso em: 6 jan. 2020. DOI: http://dx.doi.org/10.1.1.462.7531.

DEDE, C. Reconceptualizing Technology Integration to Meet the Necessity of Transformation. Journal of Curriculum and Instruction (JoCl), V. 4, No 1, p. 4-16, 2011. Disponível em: <https:// pdfs.semanticscholar.org/8352/209dfb518994bd 6e07e8f697db0a705 4d4b1.pdf>. Acesso em: 05 jan. 2020. DOI: hppt://dx.doi.org/10.3776/joci.2011.v5n1p4-16.

DELEUZE, G. Mil platôs v. 4. São Paulo: Perspectiva, 1997.

DELEUZE, G. Lógica do Sentido. Tradução Luiz Roberto Salinas Fortes. São Paulo: Perspectiva, 2011.

FAZENDA, I. C. A.; TAVARES, D. E.; GODOY, H. P. (Orgs.). Interdisciplinaridade na pesquisa científica. Campinas: Papirus, 2015. (Coleção Práxis).

FREIRE, P. Pedagogia da autonomia: saberes necessários à prática educativa. São Paulo: Paz e Terra, 1999.

GATTI, B.; ANDRÉ, M. A relevância dos métodos de pesquisa qualitativa em Educação no Brasil. In: WELLER, W.; PFAFF, N. (Orgs.). Metodologias da pesquisa qualitativa em Educação. 3. ed. Petrópolis, RJ: Vozes, 2013, p. 29-38.

KURZWEIL, R. A era das máquinas espirituais. São Paulo: Aleph, 2007.

MARQUES, I. O artista/docente: ou o que a arte pode aprender com a educação (3). ouvirOUver, v. 10, n. 2, p. 230-239, 2015. Disponível em: <http://www.seer.ufu.br/ index.php/ouvirouver/ article/view/32049>. Acesso em: 10 jan. 2020. DOI: https://doi.org/ 10.14393/OUV14v10n2a2014-4.

MCLUHAN, M. Os meios de comunicação como extensões do homem. Trad.: Décio Pignatari. São Paulo: Cultrix, 1989.

KWIATKOWSKI, P. Entrevista concedida ao portal UFPR Notícias. Curitiba, 2018. Disponível em: <https://www.ufpr.br/portalufpr/noticias/onda-exposicao-individual-do-artista-polonespawel-kwiatkowski/>. Acesso em: 14 jan. 2020.

PÉREZ GÓMEZ, A. I. Educação na era digital: a escola educativa. Trad. Marisa Guedes. Porto Alegre: Penso, 2015.

PLANO DE ENSINO da disciplina "Crítica de Dança": Curso de Bacharelado e Licenciatura em Dança - Universidade Estadual do Paraná - campus de Curitiba II (FAP), 2018. 
PLAZA, J. Tradução intersemiótica. São Paulo: Editora Perspectiva, 2003. Coleção Estudos, nº 93.

PPC - Projeto Político Pedagógico de Curso: Curso de Bacharelado e Licenciatura em Dança - Universidade Estadual do Paraná - Campus de Curitiba II (FAP), 2017.

SANTAELLA, L. A ecologia pluralista da comunicação - conectividade, mobilidade, ubiquidade. São Paulo: Paulus, 2010.

SANTAELLA, L. Comunicação ubíqua: repercussões na cultura e na educação. São Paulo: Paulus, 2013.

SIEMENS, G. Connectivism: a learning theory for the digital age. International Journal of Instruction Technology and Distance Learning, V. 2, $N^{\circ} 1$, p.1-9, 2005. Disponível em: <https://jotamac.typepad.com/jotamacs_weblog/files/ Connectivism.pdf>. Acesso em: 13 jan. 2020.

SILVA, E. R. Graduação em Dança no Brasil: professor como orientador e aluno como protagonista. In: ROCHA, T. (Org.). Graduações em dança no Brasil: o que será que será? Joinville: Nova Letra, 2016, p. 29-36. Disponível em: <http://www.ifdj.com.br/site/wp-content/ uploads/2016/07/IX-Seminarios-de-Danca-Graduacoes-em-Danca-no-Brasil_Varios-Autores. pdf>. Acesso em: 05 jan. 2020.

TARDIF. M. Saberes docentes e formação profissional. Petrópolis, RJ: Vozes, 2014.

VIGOTSKI, L. S. A construção do pensamento e da linguagem. São Paulo: Martins Fontes, 2001a.

VIGOTSKI, L. S. Psicologia da arte. São Paulo: Martins Fontes, $2001 \mathrm{~b}$.

VIGOTSKI, L. S. Psicologia pedagógica. 3. ed. São Paulo: WMF Martins Fontes, 2010.

WOSNIAK, C. A universidade e a formação do artista docente da(na) dança. O Teatro Transcende. CCEAL /FURB. Blumenau, V. 22, N. 1-2, 2017, p. 1-16. Disponível em: <http://proxy.furb.br/ojs/ index.php/oteatrotranscende/article/view/6951/3712>. Acesso em: 21 jan. 2019.

WOSNIAK, C. Miniaturas de um corpo semiótico em ambiente digital: a ciberdança em(na) rede. Vozes e Diálogo, [S.I.], v. 12, n. 02, dez. 2013. ISSN 2237-4531. Disponível em: < https:// siaiap32.univali.br/seer/index.php/vd/article/view/4802/2736>. Acesso em: 13 jan. 2020. DOI: .http://dx.doi.org/10.14210/vd.v12n02.p\%p.

YIN, R. K. Estudo de caso: planejamento e métodos. Trad. Daniel Grassi. 2. ed. Porto Alegre: Bookman, 2001.

1 Termo que denomina os celulares que possuem aplicativos - tecnologias avançadas incorporadas - que são executados por sistemas ou programas operacionais.

2 Pode-se afirmar que existem três instâncias definidoras do processo de ensinoaprendizagem em Educação: educação formal [performada em ambientes escolares formais e institucionais]; educação informal [balizada pela educação adquirida em ambientes familiares, sociais, recreativos, religiosos, de forma natural e social]; educação não formal [performada em ambientes fora do espaço formal, mas com o intuito de reforçar aspectos 
desta última, tais como visitas a museus, galerias, centros culturais e outros espaços culturais].

3 O termo "artista-docente" foi cunhado por Isabel Marques em sua pesquisa/tese de doutorado defendida em 1996, na Faculdade de Educação da Universidade de São Paulo (USP) e intitulada Dança no contexto: uma proposta para a educação contemporânea.

4 O sobrenome do autor em questão admite diferentes grafias, de acordo com as obras consultadas: Vigotsky, Vygotsky, Vygotski e Vigotski. Neste artigo, optou-se por "Vigotski" por se tratar da grafia equivalente mais próxima da língua portuguesa.

5 Pessoas que nasceram na "era digital" (a partir do ano 2000) e não conhecem a vida sem as novas tecnologias.

6 Importantes considerações e aspectos sintéticos sobre o teor dessa reformulação curricular, bem como a grade de disciplinas curriculares, podem ser acessadas por meio do Processo de N 809/17, contendo 21 páginas e referente ao assunto: "Pedido de renovação de reconhecimento do curso de graduação em Dança - Bacharelado e Licenciatura, ofertado pela Unespar, no campus de Curitiba II". Para maiores informações, consultar: <http:// www.cee.pr.gov.br/arquivos/File/pdf/Pareceres_2017/CES/pa_ces_63_17.pdf>. Acesso em: 8 jan. 2020.

7 O museu de arte da Universidade Federal do Paraná (MusA-UFPR), criado em 2002 e localizado no prédio histórico da instituição, é um espaço destinado ao estudo e à pesquisa, por meio de exposições, palestras e ações educativas. É um espaço cultural com acesso gratuito e vinculado à Coordenadoria de Cultura $(C O C)$ da Pró-Reitoria de Extensão e Cultura (PROEC) da UFPR. Para maiores informações, consultar: <http://www.musa.ufpr.br/links/ historico.html>. Acesso em: 13 jan. 2020.

8 A mostra Onda de Pawel Kwiatkowski foi organizada pela Prof. ${ }^{a}$ Dra. Dulce Osinski (Deartes/UFPR) e apresentou 20 trabalhos no formato de $80 \times 120 \mathrm{~cm}$, impressos em papel, com técnicas gráficas combinadas, ficando em exposição no Museu de Artes da UFPR no período entre 9 de março a 27 de abril de 2018.

9 Trata-se aqui de utilizar alguns aportes e com bastante moderação, a Análise de Conteúdo desenvolvida por Laurence Bardin e que consiste em um conjunto de técnicas de análise documental com o objetivo de "obter, por procedimentos sistemáticos e objetivos de descrição do conteúdo das mensagens, indicadores (quantitativos ou não) que permitam a inferência de conhecimentos relativos às condições de produção/recepção [...] destas mensagens" (BARDIN, 2002, p. 42). 